FLOOD OF AUGUST 31 - SEPTEMBER 1,1978, IN CROSSWICKS CREEK BASIN AND VICINITY, CENTRAL NEW JERSEY

U.S. GEOLOGICAL SURVEY

Water-Resources Investigations $80-115$

PREPARED IN COOPERATION WITH THE

NEW JERSEY DEPARTMENT OF ENVIRONMENTAL PROTECTION,

DIVISION OF WATER RESOURCES 


\begin{tabular}{|l|l|l|}
\hline REPORT DOCUMENTATION & 1. REPORT NO. & 2. \\
\hline PAGE
\end{tabular}

4. Titie and Subtitle

Flood of August 31-September 1, 1978, in Crosswicks Creek basin and vicinity, Central New Jersey

7. Author(s)

Arthur A. Vickers

9. Performing Organization Name and Address

U.S. Geological Survey, Water Resources Division

Room 430, Federal Building

P.0. Box 1238

402 East State Street

Trenton, New Jersey 08607

12. Sponsoring Organization Name and Address

U.S. Geological Survey, Water Resources Division

Room 430, Federal Building

P.0. Box 1238, 402 East State Street

Trenton, New Jersey 08607

15. Supplementary Notes

Prepared in cooperation with the New Jersey Department of Environmental Protection, Division of Water Resources

16. Abstract (Limit: 200 words)

A thunderstorm during the evening of August 31 and the morning of September 1, 1978, caused flooding in a small area of South-central New Jersey. Maximum peaks of record occurred on the Upper Crosswicks Creek basin in the vicinity of Fort Dix, Wrightstown, and New Egypt. At New Egypt, high water crest elevations for Crosswicks Creek were approximately 4 feet higher than the previous maximum recorded on August 28, 1971.

17. Document Analysis a. Descriptors

Flood Data, Flood Profiles, Flood Peaks, Historic Floods, Indirect Flood Measurements, Flood Stages

b. Identifiers/Open-Ended Terms

Central New Jersey, Crosswicks Creek

c. COSATI Field/Group

18. Availability Statement

No restriction on distribution, This report

may be purchased from National Technical

Information Service, Springfield, VA 22161

(See ANSI-Z39.18)

\begin{tabular}{|l|c|}
\hline $\begin{array}{l}\text { 19. Security Class (This Report) } \\
\text { UNCLASS IFIED }\end{array}$ & $\begin{array}{c}\text { 21. No. of Pages } \\
26\end{array}$ \\
\hline $\begin{array}{l}\text { 20. Security Class (This Page) } \\
\text { UNCLASSIFIED }\end{array}$ & 22. Price \\
\hline
\end{tabular}


FLOOD OF AUGUST 31-SEPTEMBER 1, 1978, IN CROSSWICKS CREEK BASIN AND VICINITY, CENTRAL NEW JERSEY

By Arthur A. Vickers

U.S. GEOLOGICAL SURVEY

Water-Resources Investigations 80-115

Prepared in cooperation with the

NEW JERSEY DEPARTMENT OF ENVIRONMENTAL PROTECTION, DIVISION OF WATER RESOURCES

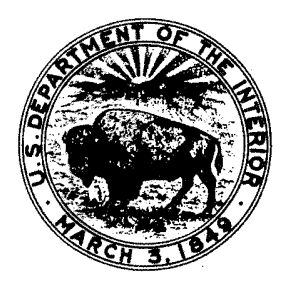

December 1980 


\section{UNITED STATES DEPARTMENT OF THE INTERIOR \\ CECIL D. ANDRUS, Secretary \\ GEOLOGICAL SURVEY \\ H. William Menard, Director}

For additional information write to:

U.S. Geological Survey

Rm. 430 Federal Building

P.O. Box 1238

Trenton, New Jersey 08607 


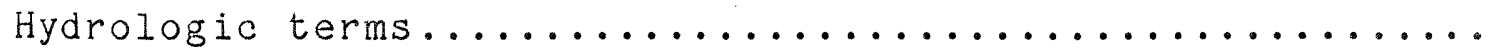

Factors for converting inch-pound units to metric units....

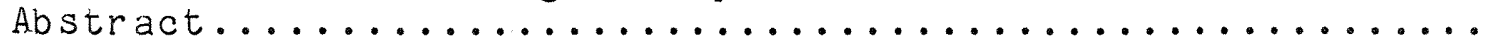

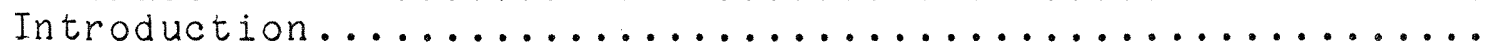

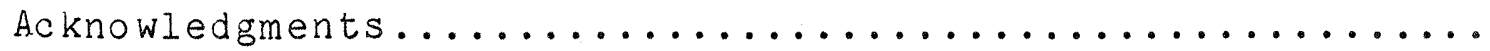

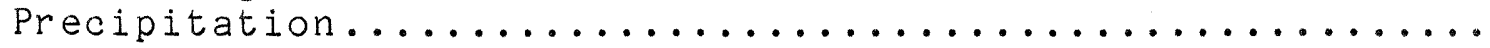

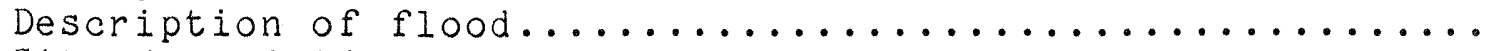

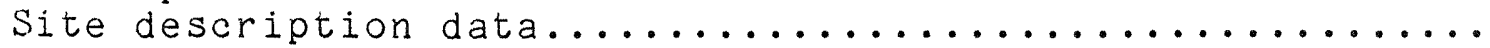

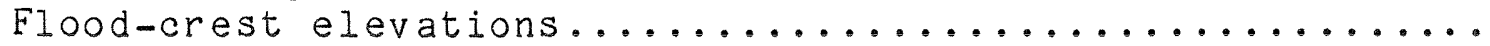

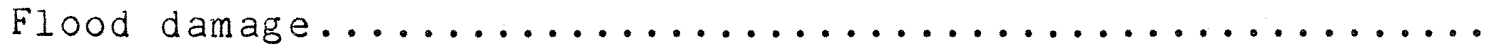

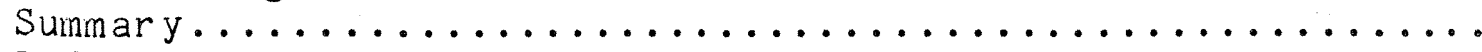

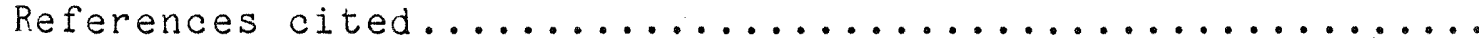

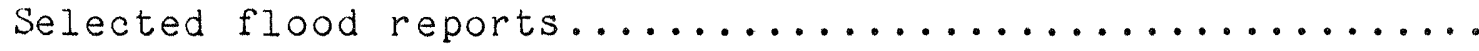

\section{ILLUSTRATIONS}

Figure 1.--Location map of flood area, August 31 -

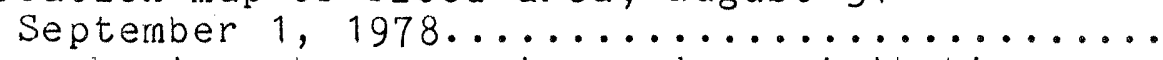
2.--Map showing stream-gaging and precipitation stations, August 31-September 1, 1978........ 3.--Elevation of Crosswicks Creek, August 28, 1971 and August 31-September 1, 1978...........

\section{TABLES}

Table 1.--Precipitation at selected stations, August 31-

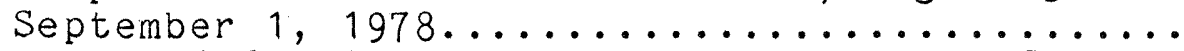
2.-- Summary of flood stages and discharges in Central New Jersey, August 31-September 1, 1978....... 3.--Flood-crest data for selected sites in Crosswicks

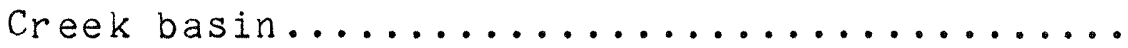




\section{EXPLANATION OF COMMONLY USED HYDROLOGIC TERMS}

Annual probability of exceedence - Probability that a random event will on the average exceed a specified magnitude annually.

Contents - the volume of water in a reservoir or lake. UnIess otherwise indicated, volume is computed on the basis of a level pool and does not include bank storage.

Crest-stage station - a particular site where only information on crest stage and peak discharge are collected systematically.

Cubic feet per second per square mile $\left[\left(\mathrm{ft}^{3} / \mathrm{s}\right) / \mathrm{mi}^{2}\right]$ - the average number of cubic feet of water flowing per second from each square mile of area drained, assuming that the runoff is distributed uniformly in time and area.

Cubic foot per second $\left(\mathrm{ft}^{3} / \mathrm{s}\right)$ - the rate of discharge representing a volume of 1 cubic foot passing a given point during 1 second, and equivalent to 7.48 gallons per second or 448.8 gallons per minute.

Discharge - the volume of water that passes a given point within a given period of time.

Drainage area - The drainage area of a stream at a specific location is that area, measured in a horizontal plane, which is enclosed by a drainage divide. Figures of drainage area given herein include all closed basins, or noncontributing areas, within the area, unless otherwise noted.

Drainage basin - a part of the surface of the earth that is occupied by a drainage system, which consists of a stream or body of impounded surface water, together with all tributary streams and bodies of impounded surface water.

Gage-height (GH) - the water-surface elevation referred to some arbitrary gage datum. Gage height is often used

interchangeably with the more general term "Stage", although gage height is more appropriate, when used with a reading on a gage.

Gaging station - a particular site on a stream, canal, lake, and reservoir where systematic observations of gage height or discharge are obtained. When used in connection with a discharge record, the term is applied only to those gaging stations where a continuous record of discharge is obtained.

Partial-record station - a particular site where only a few streamflow data are collected systematically over a period of years for use in hydrologic analyses. 
Recurrence interval (return period, exceedence interval) - the average time interval between actual occurrences of a hydrologic event of a given or greater magnitude.

National Geodetic Vertical Datum of 1929 (NGVD) - a geodetic datum derived from a general adjustment of the first order level nets of both the United States and Canada. It was formerly called "Sea Level Datum of 1929," or "mean sea level" in reports of the U.S. Geological Survey. Although the datum was derived from the average sea level over a period of many years at 26 tide stations along the Atlantic, Gulf of Mexico, and Pacific Coasts, it does not necessarily represent local mean sea level at any particular place. 
FACTORS FOR CONVERTING INCH-POUND UNITS TO METRIC UNITS

\begin{tabular}{|c|c|c|}
\hline Multiply inch-pound unit & $\underline{\text { By }}$ & To obtain metric unit \\
\hline $\begin{array}{l}\text { cubic feet per second } \\
\left(f t^{3} / s\right)\end{array}$ & 0.02832 & $\begin{array}{l}\text { cubic meters per } \\
\text { second }\left(\mathrm{m}^{3} / \mathrm{s}\right)\end{array}$ \\
\hline $\begin{array}{l}\text { cubic feet per second per } \\
\text { square mile } \\
\left(\mathrm{ft}^{3} / \mathrm{s}\right) / \mathrm{mi}^{2}\end{array}$ & 0.01093 & $\begin{array}{l}\text { cubic meters per } \\
\text { second per square } \\
\text { kilometer } \\
\left(\mathrm{m}^{3} / \mathrm{s}\right) / \mathrm{km}^{2}\end{array}$ \\
\hline feet $(f t)$ & 0.3048 & meters $(\mathrm{m})$ \\
\hline $\begin{array}{l}\text { feet per second } \\
\left(f^{t} / \mathrm{s}\right)\end{array}$ & 0.3048 & $\begin{array}{l}\text { meters per second } \\
(\mathrm{m} / \mathrm{s})\end{array}$ \\
\hline inches (in) & 25.40 & millimeters $(\mathrm{mm})$ \\
\hline miles (mi) & 1.609 & kilometers $(\mathrm{km})$ \\
\hline square feet $\left(f t^{2}\right)$ & 0.0929 & square meters $\left(\mathrm{m}^{2}\right)$ \\
\hline $\begin{array}{l}\text { square miles } \\
\left(\mathrm{mi}^{2}\right)\end{array}$ & 2.590 & $\underset{\left(\mathrm{km}^{2}\right)}{\text { square kilometers }}$ \\
\hline
\end{tabular}




\title{
FLOOD OF AUGUST 31-SEPTEMBER 1, 1978. IN CROSSWICKS CREEK BASIN AND VICINITY, CENTRAL NEW JERSEY
}

By Arthur A. Vickers

\author{
ABSTRACT
}

A thunderstorm during the evening of August 31, 1978, caused flooding in a small area of Southcentral New Jersey. Maximum peaks of record occurred on the upper Crosswicks Creek basin in the vicinity of Fort Dix, Wrightstown, and New Egypt. At New Egypt, high water crest elevations for Crosswicks Creek were approximately 4 feet higher than the previous maximum recorded on August 28, 1971. Total damages were in excess of 2 million dollars, with 70 houses and 14 businesses affected. 


\section{INTRODUCTION}

Severe flash flooding occurred over a small region of Monmouth, Burlington, and Ocean Counties, New Jersey, during the evening of August 31 and the morning of September 1, 1978. (See fig. 1). A small intense storm cell was stalled over this area on the evening of August 31 for about 6 hours before moving eastward. Extensive damage was reported in New Egypt, Ocean County, as Crosswicks Creek and Oakford Lake flooded.

Meteorologic and hydrologic data collected during this storm are recorded in this report.

This study is limited to Crosswicks Creek and adjoining basins, as heavy rains occurred only over the New Egypt, Wrightstown, and Fort Dix areas. Weather stations close to this region reported no rainfall or only moderate rainfall. Less than 1.5 inches of precipitation was reported within $5-10 \mathrm{mi}$ of the storm's center. (See fig. 2, p. 4.)

\section{ACKNOWLEDGMENTS}

This report was prepared by the U.S. Geological Survey in cooperation with the New Jersey Department of Environmental Protection, Division of Water Resources. Valuable assistance was received from the Burlington County Times and personnel at Fort Dix and McGuire Air Force Base. The National Oceanic and Atmospheric Administration (National Weather Service) furnished precipitation and radarscope data.

\section{PRECIPITATION}

The National Weather Service's (NWS) radar sites at Atlantic City, N.J., and Long Island, N.Y., noted a small intense weather cell over the New Egypt-Fort Dix area from about 4 to 10 p.m. on August 31, 1978. Clouds reached an altitude of 35,000 ft. The Fort Dix Fire Tower reported rainfall in excess of 9 inches. McGuire Air Force Base reported 7.40 inches on August 31, with 2.47 inches recorded between 8 and $9 \mathrm{p} . \mathrm{m}$. The locations of these and other stations are shown on figure 2. One inch of rain fell in this area within a 20-minute period. At approximately 4:30 p.m., 0.5-inch hailstones fell. This intense storm affected an area less than $35 \mathrm{mi}^{2}$. Unless otherwise noted, precipitation data in table 1 was furnished by the National Oceanic and Atmospheric Administration, Environmental Data and Information Service. 


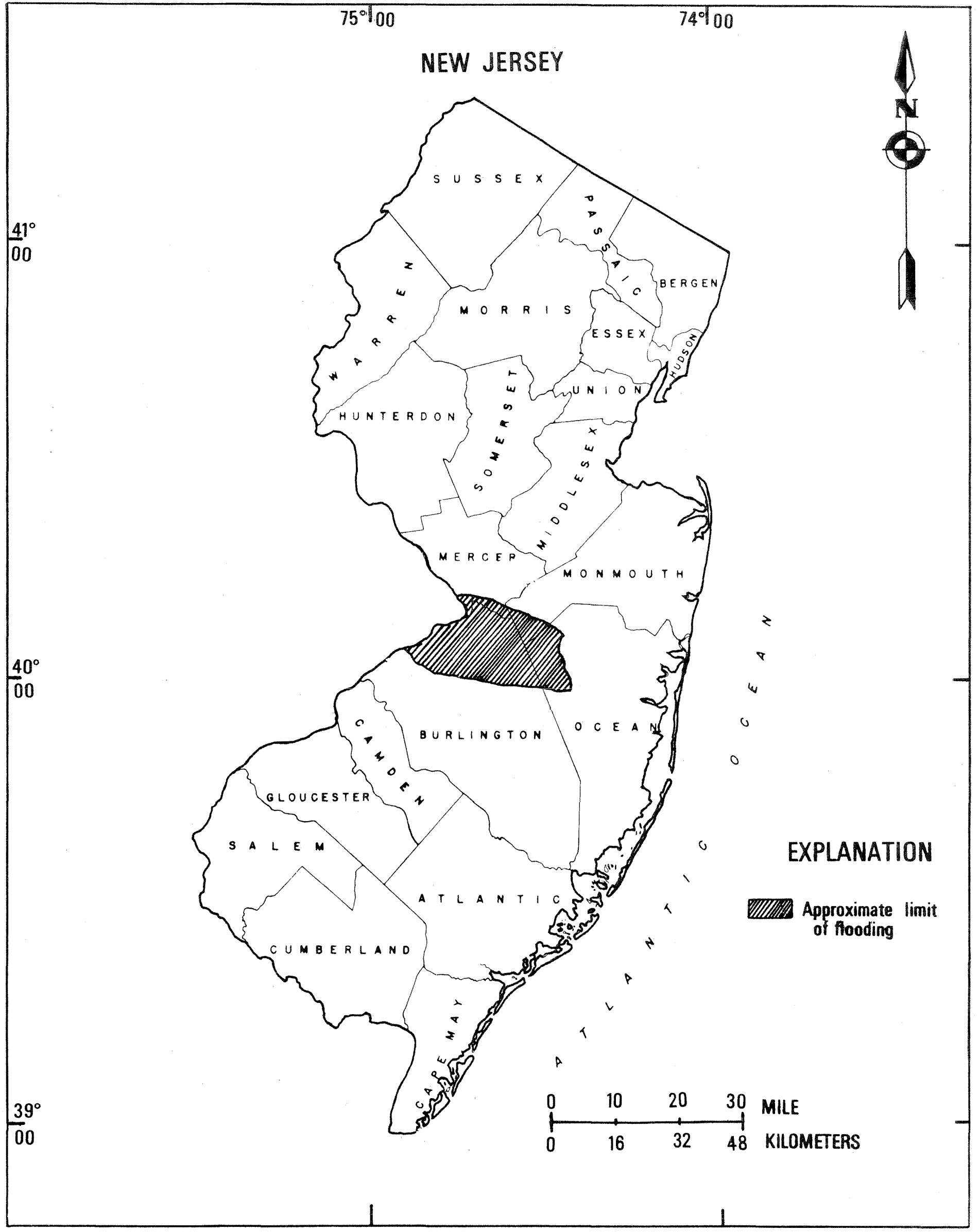

FIGURE 1. - Location map showing area of flooding on August 31-5eptembor 1, 1978, in Central Now Jersey. 


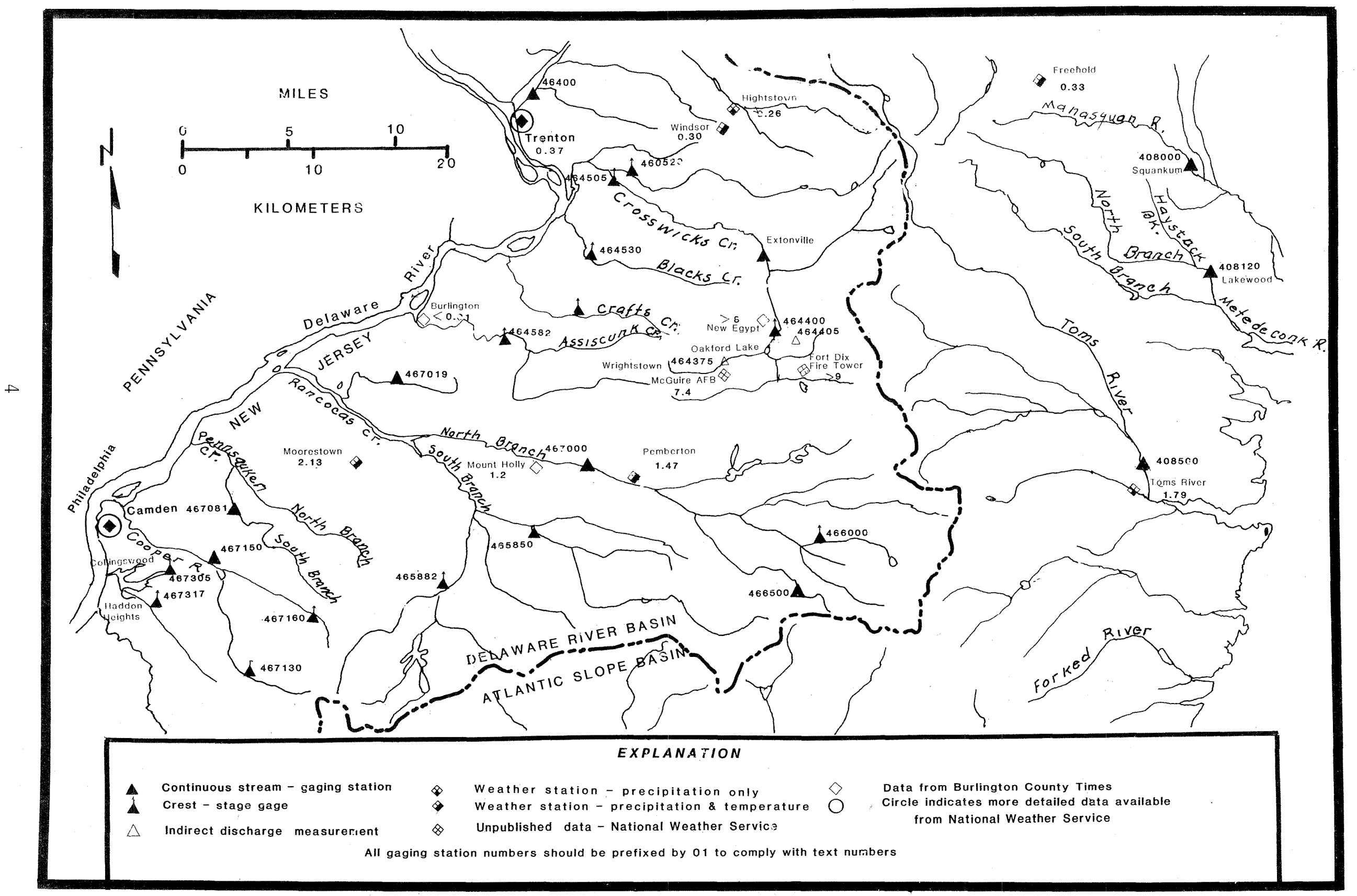

Figure 2. - Map showing stream - gaging and precipitation stations at various locations in Central New Jersey for the flood of August 31 - September 1 , 1978. 
Table 1.--Precipitation at selected stations for the flood of August 31-September 1, 1978

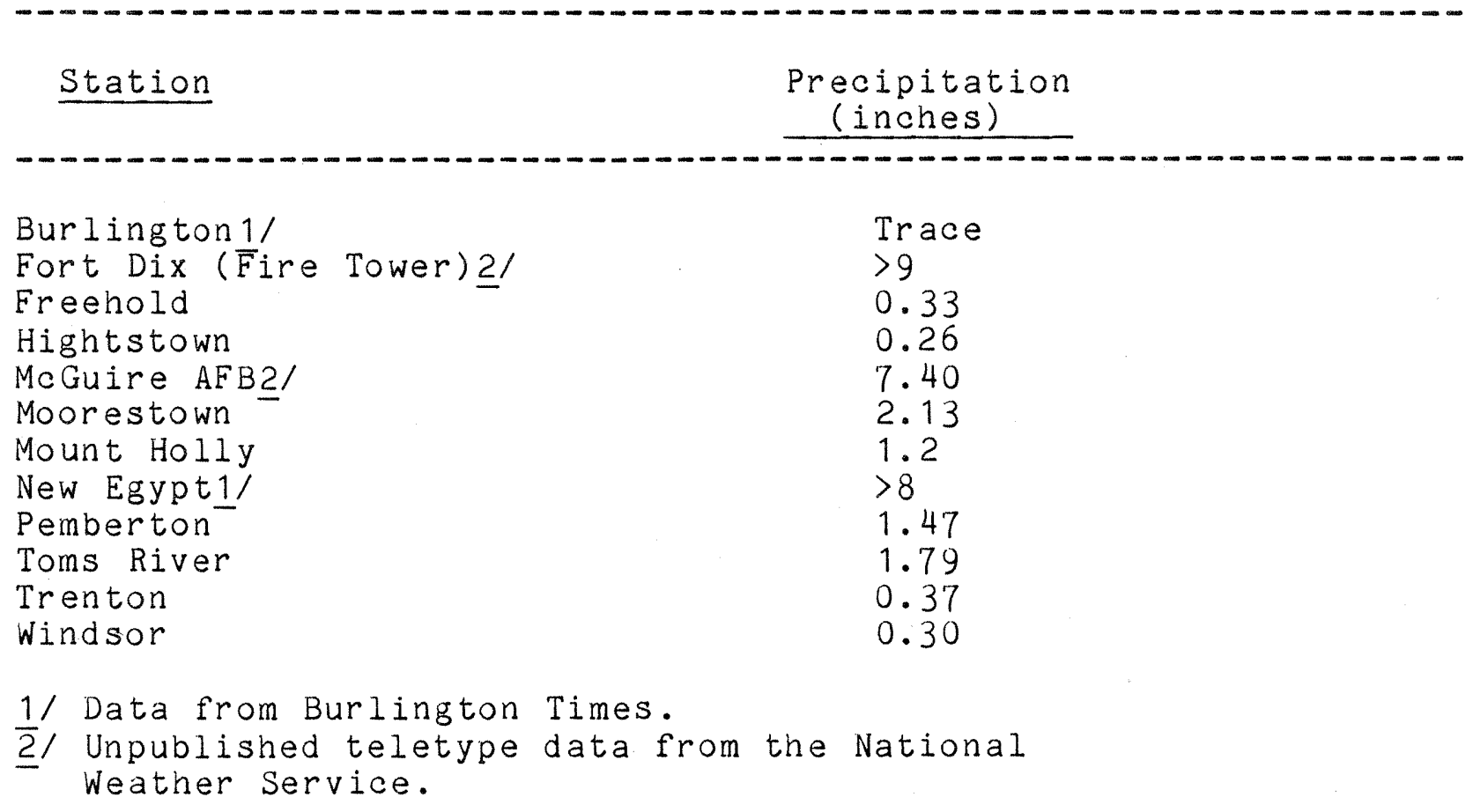

\section{DESCRIPTION OF FLOOD}

The flood crest of August 31-September 1, 1978, established a new maximum peak stage of record for the crest stage gage on Crosswicks Creek at New Egypt (Station No. 01464400). This maximum exceeded by over 3.9 ft the previous highest stage on August 28, 1971. (See fig. 3, p. 6.) At the regular daily streamflow station, Crosswicks Creek at Extonville (Station No. 01464500), the previous maximum stage, also on August 28, 1971, was exceeded by about $0.25 \mathrm{ft}$. From the village of Crosswicks to the mouth of the stream, the flood of August 28, 1971, remains the maximum of record.

On August 26-28, 1971, thunderstorins after tropical storm, Doria, caused heavy precipitation ( 3 to 11 inches) over all of New Jersey for about 32 hours. In comparison, the flood of August 28September 1, 1978, was caused by a small, intense thunder cell, approximately $10 \mathrm{mi}$ in diameter, that stalled over New Egypt, Wrightstown, and Fort Dix for about 6 hours. Up to 9 inches of rain fell during that time. The magnitude of the flood of Crosswicks Creek at New Egypt on September 1, 1978, will be exceeded, on the average, once every 75 years based upon guidelines of the U.S. Water Resources Council (1977). A comparison of the flood profiles resulting from the storms of August 28, 1971, and August 31-September 1, 1978, is shown in figure 3 [high-water marks identified and elevations determined by U.S. Geological Survey (USGS) personnel immediately after each flood]. 


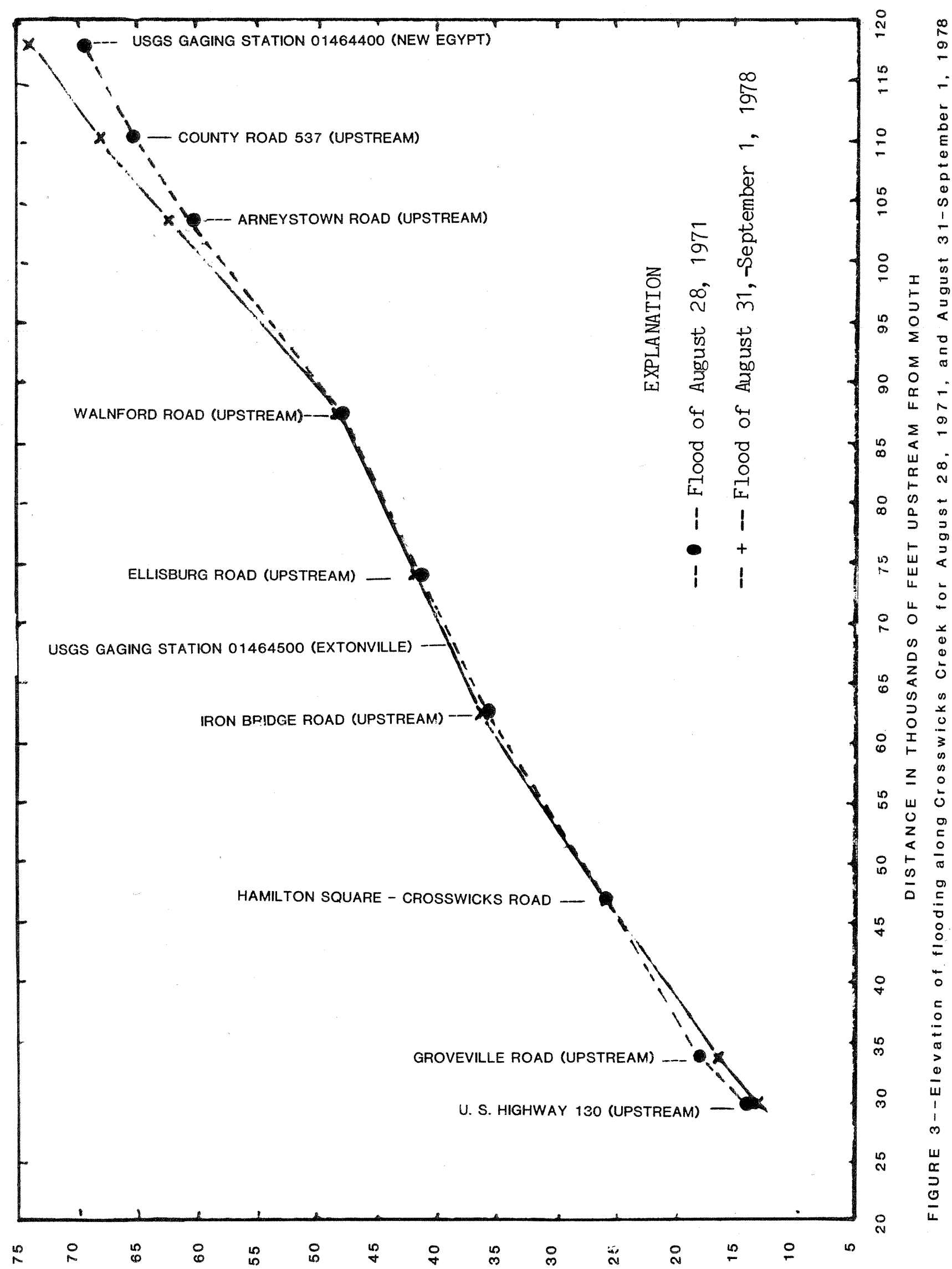

ELEVATION, IN FEET, NATIONAL GEODETIC VERTICAL DATUM OF 1929 
Blacks, Crafts, and Assiscunk Creeks also flooded to some extent after this storm, but data are insufficient for comparison with previous floods in these areas.

From August 31 to September 1, 1978, new peaks of record were recorded on Newton Creek at Collingswood (Station No.

01467305) and South Branch Newton Creek at Haddon Heights (Station No. 01467317). Both peaks were the highest since the beginning of record. However, these peaks were probably the result of a storm other than the one that caused the Crosswicks Creek flood, as numerous small thunder cells were noted over Central New Jersey during August 28 to september 2, 1978.

Table 2 summarizes hydrologic data for the Crosswicks Creek flood and similar information for other floods in the region. 
Table 2.--Summary of flood stages and discharges in Central New Jersey for the flood of August 31-September 1 , 1978

\begin{tabular}{|c|c|c|c|c|c|c|c|c|c|c|c|c|}
\hline $\begin{array}{l}\text { Station } \\
\quad \text { No. }\end{array}$ & Stream and place of determination & $\begin{array}{l}\text { Drainage } \\
\text { area } \\
\left(\mathrm{mi}^{2}\right)\end{array}$ & $\begin{array}{l}\text { Period } \\
\text { of } \\
\text { record }\end{array}$ & $\begin{array}{l}\text { Maximum } \\
\text { Date }\end{array}$ & $\begin{array}{l}\text { flood pr } \\
\text { Gage } \\
\text { height } \\
\text { (ft) }\end{array}$ & $\begin{array}{r}\text { Dise } \\
\left(\mathrm{ft}^{3} / \mathrm{s}\right)\end{array}$ & $\begin{array}{l}\text { ly known } \\
\text { harge } \\
\left(\mathrm{ft}^{3} / \mathrm{mi}^{2}\right)\end{array}$ & Maximum & $\begin{array}{l}\text { during } p \\
\text { Gage } \\
\text { height } \\
(f t)\end{array}$ & $\begin{array}{r}\text { present } f \\
\text { Discl } \\
\left(\mathrm{ft} \mathrm{t}^{3} / \mathrm{s}\right)\end{array}$ & $\begin{array}{l}\text { lood } \\
\text { harge } \\
\left(\mathrm{ft}^{3} / \mathrm{mi}^{2}\right)\end{array}$ & $\begin{array}{c}\text { Annual } \\
\text { probability } \\
\text { of } \\
\text { exceedance }\end{array}$ \\
\hline 01408000 & Manasquan River at Squankum & 43.4 & $1931-78$ & $9 / 21 / 38$ & 12.45 & 2,940 & 67.7 & Sept. 1 & 3.91 & 322 & 7.41 & $0.99+$ \\
\hline 01408120 & NB Metedeconk $\mathrm{R} n \mathrm{nr}$ Lakewood & 34.9 & $1972-78$ & $11 / 08 / 77$ & 9.28 & 1,370 & 39.3 & Sept. 1 & 5.53 & 176 & 5.00 & $0.99+$ \\
\hline 01408500 & Toms River near Toms River & 124 & $1928-78$ & $9 / 23 / 38$ & 12.50 & 2,000 & 16.1 & Sept. 1 & 9.76 & 1,200 & 9.67 & 0.15 \\
\hline 01464000 & Assunpink Creek at Trenton & 89.4 & $1938-78$ & $7 / 21 / 75$ & 14.61 & 5,450 & 61.0 & Sept. 1 & 3.99 & 301 & 3.36 & $0.99+$ \\
\hline 01464375 & North Run near Cookstown & 4.66 & 1978 & - & - & - & - & Aug. 31 & - & 1,860 & 399 & af \\
\hline 01464400 & Crosswicks Creek at New Egypt & 37.5 & $1968-78$ & $8 / 28 / 71$ & 26.3 & 1,940 & 51.2 & Sept. 1 & 30.27 & 4,500 & 120 & 0.01 \\
\hline 01464405 & Crosswicks Trib No. 2 at New Egypt & 1.02 & 1978 & - & - & & - & Aug. 31 & - & 340 & 333 & \\
\hline 01464500 & Crosswicks Creek at Extonville & 83.6 & $1940-78$ & $8 / 28 / 71$ & 13.93 & 4,640 & 55.5 & Sept. 1 & 14.22 & 4,860 & 58.1 & 0.04 \\
\hline 01464505 & Crosswicks Creek at Groveville & 94.5 & $1968-78$ & $8 / 28 / 71$ & 16.21 & - & - & Sept. 1 & 14.88 & - & - & b/ \\
\hline 01464520 & Doctors Creek at Groveville & 25.3 & $1968-78$ & $1 / 26 / 78$ & 9.33 & 2,080 & 82.2 & Sept. 1 & 5.59 & 125 & 4.94 & $0.99+$ \\
\hline 01464530 & Blacks Creek at Mansfield Square & 19.7 & 1978 & - & - & - & - & Aug. 31 & 11.2 & 2,500 & 127 & a) \\
\hline 01464538 & Crafts Creek at Columbus & 5.38 & 1978 & - & - & - & - & Aug. 31 & 9.12 & 328 & 30.9 & $\bar{a} /$ \\
\hline 01464582 & Assiscunk Creek near Columbus & 1.09 & 1978 & - & - & - & - & Aug. 31 & 11.1 & 1,420 & 171 & $\bar{a} /$ \\
\hline 01465850 & SB Rancocas Creek at Vincentown & 53.3 & $1962-78$ & $8 / 28 / 78$ & 7.98 & 1,320 & 24.8 & Sept. 1 & 5.65 & 455 & 8.54 & 0.95 \\
\hline 01465882 & SW Branch Rancocas $\mathrm{CK}$ at Medford & 47.9 & $1975-78$ & $9 / 25 / 75$ & 7.21 & 4,600 & 96.0 & Sept. 1 & 6.69 & 3,500 & 73.1 & a) \\
\hline 01466000 & Middle Branch Mt Misery Brook & 2.52 & $1952-78$ & $5 / 29 / 68$ & 2.52 & 50 & 18.3 & Sept. 1 & 1.35 & 1.0 & 37 & $0.99+$ \\
\hline 01466500 & McDonalds $\mathrm{Br}$ in Lebanon St Forest & 2.31 & $1953-78$ & $8 / 25 / 58$ & 2.33 & 35 & 15.2 & Sept. 1 & 1.39 & 3.6 & 87 & $0.99+$ \\
\hline 01467000 & NB Rancocas Creek at Penberton & 111 & $1921-78$ & $8 / 31 / 39$ & 4.23 & 1,730 & 15.6 & Sept. 1 & 2.42 & 712 & 6.41 & 0.60 \\
\hline 01467019 & Mill Creek near willingboro & 4.12 & $1976-78$ & $1 / 26 / 78$ & 9.20 & 440 & 107 & Aug. 31 & 9.46 & 492 & 119 & \\
\hline 01467081 & SB Pennsauken CK at Cherry Hill & 9.16 & $1967-78$ & $8 / 28 / 78$ & 10.19 & 868 & 94.8 & Aug. 31 & 5.82 & 236 & 25.8 & $0.99+$ \\
\hline 01467130 & Cooper River at Kirkwood & 12.8 & $1964-78$ & $8 / 10 / 67$ & 2.47 & 390 & 30.5 & & & & & \\
\hline 01467150 & Cooper River at Haddonfield & 17.4 & $1963-78$ & $8 / 28 / 71$ & 5.46 & 3,300 & 190 & & & & & \\
\hline $\begin{array}{l}01467160 \\
01467305 \\
01467317\end{array}$ & $\begin{array}{l}\text { NB Cooper River near Marlton } \\
\text { Newton Creek at Collingswood c/ }\end{array}$ & $\begin{array}{r}5.33 \\
1.32 \\
1.62\end{array}$ & $\begin{array}{l}1964-78 \\
1964-78\end{array}$ & $\begin{array}{l}1 / 14 / 68 \\
8 / 28 / 71\end{array}$ & $\begin{array}{l}4.47 \\
5.18\end{array}$ & 320 & $\begin{array}{l}60.0 \\
186 \\
238\end{array}$ & $\begin{array}{l}\text { Aug. } 31 \\
\text { Sept. } 1 \\
\text { Sept. } 1\end{array}$ & $\begin{array}{l}1.94 \\
4.30 \\
6.40\end{array}$ & $\begin{array}{l}126 \\
330 \\
307 \\
295\end{array}$ & $\begin{array}{l}7.24 \\
61.9 \\
233 \\
468\end{array}$ & $\begin{array}{l}0.99+ \\
0.04 \\
0.04\end{array}$ \\
\hline 01467317 & SB Newton Creek at Haddon Heights $c$ f & 0.63 & $1964-78$ & $8 / 28 / 71$ & 4.18 & 150 & 238 & Sept. 1 & 4.62 & 295 & 468 & 0.03 \\
\hline $\begin{array}{ll}\text { a/ } & \text { Insuf } \\
\text { b/ Disch } \\
\text { c/ }\end{array}$ & $\begin{array}{l}\text { ficient data for determination } \\
\text { arge not determined } \\
\text { caused by other storm cells }\end{array}$ & & & & & & & & & & & \\
\hline
\end{tabular}


Descriptive data for the sites listed in table 2 are given in the following section.

\section{MANASQUAN RIVER AT SQUANKUM, NJ}

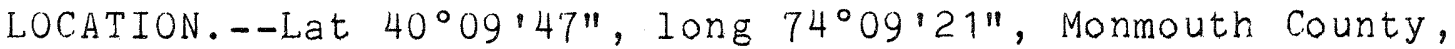
Hydrologic Unit 2040301, on right bank 20 ft downstream of bridge on State Highway 547 (Squankum Park Road) in Squankum, and $0.4 \mathrm{mi}$ downstream from Marsh Bog Brook.

DRAINAGE AREA.--43.4 $\mathrm{mi}^{2}$.

PERIOD OF RECORD. =-July 1931 to September 1978.

STATION INFORMATION.--Water-stage recorder and concrete control. Datum of gage is $18.82 \mathrm{ft}$ National Geodetic Vertical Datum of 1929. Prior to August 13, 1940, water-stage recorder at site $80 \mathrm{ft}$ upstream at same datum.

01408120 NORTH BRANCH METEDECONK RIVER NEAR LAKEWOOD, NJ

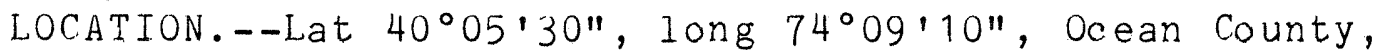
Hydrologic Unit 02040301, on upstream right bank at bridge on State Route $549,1.0 \mathrm{mi}$ upstream from confluence with South Branch Metedeconk River, and $2.3 \mathrm{mi}$ east of Lakewood.

DRAINAGE AREA.--34.9 $\mathrm{mi}^{2}$.

PERIOD OF RECORD.--October 1972 to September 1978.

STATION INFORMATION.--Water-stage recorder. Datum of gage is $3.89 \mathrm{ft}$ National Geodetic Vertical Datum of 1929.

\section{TOMS RIVER AT TOMS RIVER, NJ}

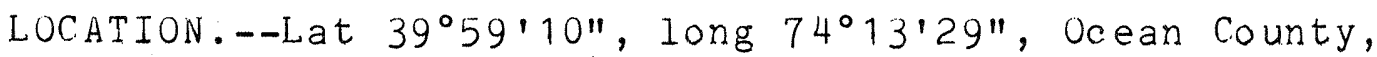
Hydrologic Unit 02040301 , on left bank $1.9 \mathrm{mi}$ downstream from Union Branch, and $2.6 \mathrm{mi}$ northwest of Toms River.

DRAINAGE AREA.--124 $\mathrm{mi}^{2}$.

PERIOD OF RECORD.--October 1928 to September 1978.

STATION INFORMATION.--Water-stage recorder. Datum of gage is $8.10 \mathrm{ft}$ National Geodetic Vertical Datum of 1929. 


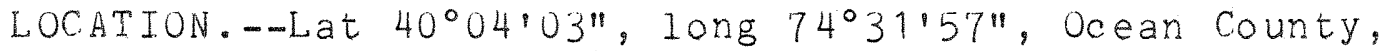
Hydrologic Unit 02040201, at upstream side of bridge on State Route 528 in New Egypt, 300 ft downstream from Oakford Lake Dam.

DRAINAGE AREA. $--37.5 \mathrm{mi}^{2}$.

PERIOD OF RECORD.--October 1967 to September 1978.

STATION INFORMATION.--Crest-stage partial record station only. Datum of gage is $43.46 \mathrm{ft}$ National Geodetic Vertical Datum of 1929.

\section{NORTH RUN NEAR COOKSTOWN, NJ}

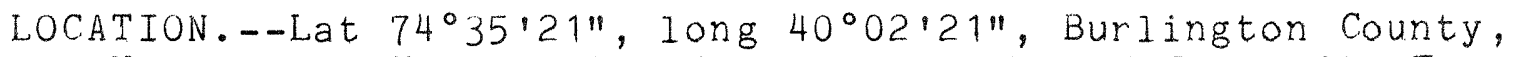
Hydrologic Unit 02040201, at culvert on McGuire Air Force Base Access Road opposite Main Gate and $1.5 \mathrm{mi}$ southwest of Cookstown.

DRAINAGE AREA. $--4.66 \mathrm{mi}^{2}$.

PERIOD OF RECORD.--Indirect discharge determination of the peak of August 31, 1978, made from the flow through culvert under McGuire Air Force Access Road.

01464405 CROSSWICKS TRIBUTARY NO. 2 AT NEW EGYPT, NJ

LOCATION. - Lat $40^{\circ} 04^{\prime} 43^{\prime \prime}$, Iong $75^{\circ} 30^{\prime} 00^{\prime \prime}$, Ocean County, Hydrologic Unit 02040201, at culvert on Lakewood Road, $1.0 \mathrm{mi}$ upstream from confluence with Crosswicks Creek and $0.8 \mathrm{mi}$ from Route 528 and Railroad Avenue in the center of village of New Egypt.

DRAINAGE AREA.--1.02 $\mathrm{mi}^{2}$.

PERIOD OF RECORD.--Indirect discharge measurement of the peak of August 31, 1978, made from the flow through culvert and road overflow. 


\section{CROSSWICKS CREEK AT EXTONVILLE, NJ}

LOCATION.--Lat $40^{\circ} 08^{\prime} 15$, long $74^{\circ} 36^{\prime} 02^{\prime \prime}$, Mercer County, Hydrologic Unit 02040201 , on right bank upstream from highway bridge at Extonville, $0.5 \mathrm{mi}$ upstream of Pleasant Run, and $0.7 \mathrm{mi}$ downstream from Mercer-Monmouth County Line.

DRA INAGE AREA. $--83.6 \mathrm{mi}^{2}$.

PERIOD OF RECORD.--October 1939 to September 1978.

STATION INFORMATION.--Water-stage recorder and concrete control. Datum of gage is 24.94 ft National Geodetic Vertical Datum of 1929.

01464505 CROSSWICKS CREEK AT GROVEVILLE, NJ

LOCATION. - Lat 40'10'26", Iong $74^{\circ} 40^{\prime} 48^{\prime \prime}$, Burlington County, Hydrologic Unit 02040201, at U.S. Highway 130, 0.3 mi upstream from Doctors Creek, $0.5 \mathrm{mi}$ northwest of Groveville, and $0.6 \mathrm{mi}$ southwest of Yardville.

DRAINAGE AREA. $--94.5 \mathrm{mi}^{2}$.

PERIOD OF RECORD.--October 1967 to September 1978.

STATION INFORMATION.--Crest-stage partial record station only. Datum of gage is $-2.15 \mathrm{ft}$ National Vertical Datum of 1929 .

\section{DOCTORS CREEK AT GROVEVILLE, N J}

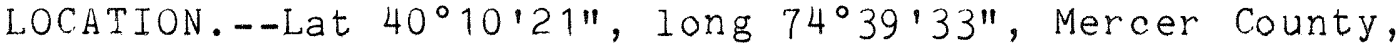
Hydrologic Unit 02040201, at bridge on GrovevilleAllentown road at Groveville, $0.7 \mathrm{mi}$ southeast of Yardville, and $1.5 \mathrm{mi}$ upstream of mouth.

DRAINAGE AREA. $--25.3 \mathrm{mi}^{2}$.

PERIOD OF RECORD.--October 1967 to September 1978.

STATION INFORMATION.--Crest-stage partial record station only. Datum of gage is $14.23 \mathrm{ft}$ National Geodetic Vertical Datum of 1929. 


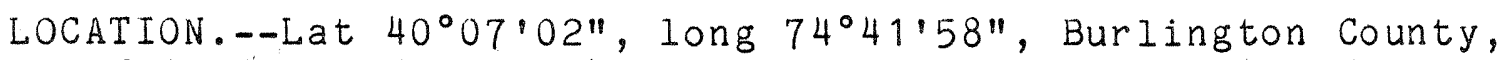
Hydrologic Unit 02040201, at bridge on Mansfield SquareCrosswicks Road, $0.4 \mathrm{mi}$ east of Mansfield Square, and $3.4 \mathrm{mi}$ above mouth.

DRAINAGE AREA. $--19.7 \mathrm{mi}^{2}$.

PERIOD OF RECORD.--August 1978.

STATION INFORMATION.--Peak discharge of the flood of August 31,1978 made on the basis of indirect determination of flow through bridge and over highway. Crest-stage partial record station established after the peak had receded. Datum of gage is $12.44 \mathrm{ft}$ National Geodetic Vertical Datum of 1929. Site was utilized as a low-flow partial record station from October 1965 to September 1972.

\section{CRAFTS CREEK AT COLUMBUS, NJ}

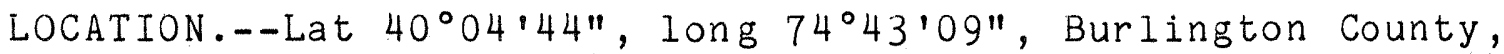
Hydrologic Unit 02040201 , at bridge on Columbus-Mansfield Road, $0.4 \mathrm{mi}$ north of Columbus and $0.9 \mathrm{mi}$ south of Mansfield.

DRAINAGE AREA $=-5.38 \mathrm{mi}^{2}$.

PERIOD OF RECORD.--August 1978.

STATION INFORMATION.--Crest-stage partial record station established after the flood of August 31, 1978. Datum of gage is 33.71 ft National Geodetic Vertical Datum of 1929 .

\section{ASSISCUNK CREEK NEAR COLUMBUS, N J}

LOCATION.--Lat $40^{\circ} 03^{\prime} 20^{\prime \prime}$, Iong $7^{\circ} 4^{\circ} 4^{\prime} 36^{\prime \prime}$, Burlington County, Hydrologic Unit 02040201, at bridge on Petticoat Bridge Road, $600 \mathrm{ft}$ downstream from Assiscunk Branch, and $1.7 \mathrm{mi}$ southwest of Columbus.

DRAINAGE AREA.--10.9 $\mathrm{mi}^{2}$.

PERIOD OF RECORD.--August 1978.

STATION INFORMATION.--Crest-stage partial record station established after the flood of August 31, 1978. 
01465850 SOUTH BRANCH RANCOCAS CREEK AT VINCENTOWN, NJ

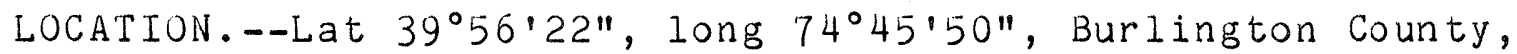
Hydrologic Unit 02040201 , on left bank 150 ft downstream from highway bridge on Lumberton-Vincentown Road, $0.8 \mathrm{mi}$ west of Vincentown, $2.9 \mathrm{mi}$ southeast of Lumberton, and $3.1 \mathrm{mi}$ upstream from Southwest Branch.

DRAINAGE AREA. $--53.3 \mathrm{mi}^{2}$.

PERIOD OF RECORD.--October 1961 to September 1978.

STATION INFORMATION.--Water-stage recorder, October 1961 to September 1975. Crest-stage partial record station, October 1975 to September 1978. Datum of gage is 13.17 ft National Geodetic Vertical Datum of 1929.

01465882 SOUTHWEST BRANCH RANCOCAS CREEK AT MEDFORD, NJ

LOCATION.--Lat 39 $54^{\circ} 16^{\prime \prime}$, long $74^{\circ} 48^{\prime 4} 47^{\prime \prime}$, Burlington County, Hydrologic Unit 02040201 , at bridge on State Route 70 , $0.6 \mathrm{mi}$ northeast of Medford, and $4.2 \mathrm{mi}$ upstream from mouth.

DRAINAGE AREA.- $-47.9 \mathrm{mi}^{2}$.

PERIOD OF RECORD.--October 1975 to September 1978.

STATION INFORMATION.--Crest-stage partial record station only. Datum of gage is $20.72 \mathrm{ft}$ National Geodetic Vertical Datum of 1929.

\section{MIDDLE BRANCH MOUNT MISERY BROOK IN LEBANON STATE FOREST, N J}

LOCATION. - Lat 39 $55^{\circ} 00^{\prime \prime}$, long $74^{\circ} 30^{\prime} 30^{\prime \prime}$, Burlington County, Hydrologic Unit 02040202, 20 ft upstream from bridge on North Branch Road in Lebanon State Forest, $5.1 \mathrm{mi}$ southeast of Browns Mills.

DRAINAGE AREA.--2.73 $\mathrm{mi}^{2}$.

PERIOD OF RECORD.--October 1952 to September 1978.

STATION INFORMATION.--Water-stage recorder from October 1952 to September 1965, crest-stage partial record station from October 1966 to September 1978. Datum of gage is 99.71 ft National Geodetic Vertical Datum of 1929. 
01466500 MCDONALDS BRANCH IN LEBANON STATE FOREST, NJ (Hydrologic bench-mark station)

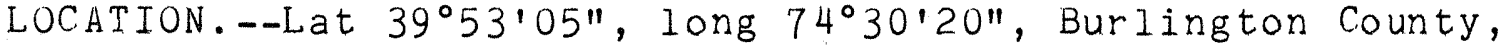
Hydrologic Unit 02040202, on right bank in Lebanon State Forest, 25 ft upstream from Butterworth Road Bridge, $3.4 \mathrm{mi}$ upstream from confluence with Cooper Branch, and $7.0 \mathrm{mi}$ southeast of Browns Mills.

DRA INAGE AREA. $--2.31 \mathrm{mi}^{2}$.

PERIOD OF RECORD.--October 1953 to September 1978. Prior to October 1962, published as "McDonald Branch in Lebanon state Forest".

STATION INFORMÁTION.--Water-stage recorder and concrete control. Datum of gage is $117.73 \mathrm{ft}$ National Geodetic Vertical Datum of 1929.

01467000 NORTH BRANCH RANCOCAS CREEK AT PEMBERTON, NJ

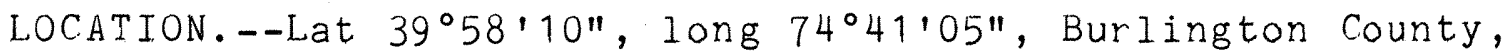
Hydrologic Unit 02040202, on right bank at downstream side of highway bridge at Pemberton, 12 mi upstream from confluence with South Branch.

DRA INAGE AREA.--111 $\mathrm{mi}^{2}$.

PERIOD OF RECORD.--September 1921 to September 1978.

STATION INFORMATION.--Water-stage recorder above concrete dams. Datum of gage is $31.19 \mathrm{ft}$ National Geodetic Vertical Datum of 1929. Prior to June 9, 1923, nonrecording gage and June 9, 1923 to Aug. 9, 1951, water-stage recorder at site $600 \mathrm{ft}$ downstream at datum $6.54 \mathrm{ft}$ lower.

\section{MILL CREEK NEAR WILLINGBORO, N J}

LOCATION. --Lat $40^{\circ} 01^{\prime} 53^{\prime \prime}$, long $74^{\circ} 51 \cdot 14^{\prime \prime}$, Burlington County, Hydrologic Unit 02040202, on left upstream wingwall of bridge on Springside Avenue, $2.2 \mathrm{mi}$ upstream from South Branch Mill Creek, $0.2 \mathrm{mi}$ east of Willingboro, and $4.6 \mathrm{mi}$ upstream from mouth.

DRAINAGE AREA. $--4.12 \mathrm{mi}^{2}$.

PERIOD OF RECORD.--October 1975 to September 1978.

STATION INFORMATION.--Water-stage recorder. Datum of gage is $21.65 \mathrm{ft}$ National Geodetic Vertical Datum of 1929. 
01467081 SOUTH BRANCH PENNSAUKEN CREEK AT CHERRY HILL, NJ

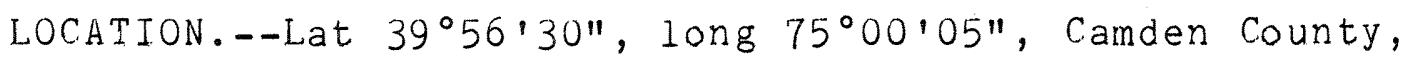
Hydrologic Unit 02040202, on left bank on downstream wingwall of bridge on Mill Road in Cherry Hill, $1.1 \mathrm{mi}$ south of Maple Shade, and $3.8 \mathrm{mi}$ upstream from confluence with North Branch.

DRAINAGE AREA. - -9.16 $\mathrm{mi}^{2}$.

PERIOD OF RECORD.--October 1967 to September 1976, October 1977 to September 1978.

STATION INFORMATION.-Water-stage recorder. Datum of gage is $8.12 \mathrm{ft}$ National Geodetic Vertical Datum of 1929.

\section{COOPER RIVER AT KIRKWOOD, N J}

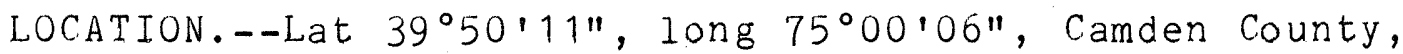
Hydrologic Unit 02040202, at outlet of Kirkwood Lake in Kirkwood, $100 \mathrm{ft}$ east of tracks of Pennsylvania-Reading Seashore Lines, and $1.0 \mathrm{mi}$ north of Laurel Springs.

DRAINAGE AREA. $--5.14 \mathrm{mi}^{2}$.

PERIOD OF RECORD.--October 1963 to September 1978.

STATION INFORMATION.--Crest-stage partial record station only. Datum of gage is $57.82 \mathrm{ft}$ National Geodetic Vertical Datum of 1929. Also operated as a low-flow partial record site.

\section{COOPER RIVER AT HADDONFIELD, $\mathrm{N} \mathrm{J}$}

LOCATION.--Lat 39 54'11", long $75^{\circ} 01^{\prime} 19^{\prime \prime}$, Camden County, Hydrologic Unit 02040202, on right bank of Wallworth Lake in Pennypacker Park, 200 ft upstream from bridge on State Highway 41 (Kings Highway) in Haddonfield, $0.6 \mathrm{mi}$ upstream from North Branch Cooper River, and $7.7 \mathrm{mi}$ upstream from mouth.

DRAINAGE AREA. $--17.4 \mathrm{mi}^{2}$.

PERIOD OF RECORD.--October 1963 to September 1978.

STATION INFORMATION.--Water-stage recorder above a cut-stone dam. Datum of gage is 9.29 ft National Geodetic Vertical Datum of 1929. 
01467160 NORTH BRANCH COOPER RIVER NEAR MARLTON, NJ

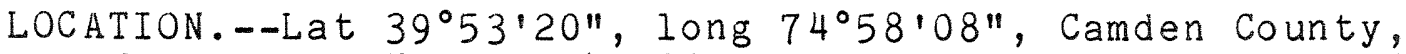
Hydrologic Unit 02040202 , at bridge on blacktop road to Springdale, $2.5 \mathrm{mi}$ west of Marlton.

DRAINAGE AREA. $--5.33 \mathrm{mi}^{2}$.

PERIOD OF RECORD.--October 1963 to September 1978.

STATION INFORMATION.--Crest-stage partial record station

only. Datum of gage is $36.36 \mathrm{ft}$ National Geodetic

Vertical Datum of 1929.

01467305 NEWTON CREEK AT COLLINGSWOOD, N J

LOCATION.--Lat 39 $54^{\prime} 30^{\prime \prime}$, long $75^{\circ} 03^{\prime} 13^{\prime \prime}$, Camden County, Hydrologic Unit 02040202, at bridge on Park Avenue in Collingswood, $0.3 \mathrm{mi}$ east of Cuthbert Avenue.

DRAINAGE AREA.--1.32 $\mathrm{mi}^{2}$.

PERIOD OF RECORD.--October 1963 to September 1978.

STATION INFORMATION.--Crest-stage partial record station

only. Datum of gage is $18.74 \mathrm{ft}$ National Geodetic

Vertical Datum of 1929.

01467313 SOUTH BRANCH NEWTON CREEK AT HADDON HEIGHTS, NJ

LOCATION.--Lat 39 $52^{\prime} 45^{\prime \prime}$, long $75^{\circ} 04^{\prime} 26^{\prime \prime}$, Camden County, Hydrologic Unit 02040202, at bridge in Haddon Heights Park, and $2.6 \mathrm{mi}$ south of Collingswood.

DRAINAGE AREA.--0.63 $\mathrm{mi}^{2}$.

PERIOD OF RECORD.--October 1963 to September 1978.

STATION INFORMATION.--Crest-stage gaging station only. Datum of gage is $23.34 \mathrm{ft}$ National Geodetic Vertical Datum of 1929. 


\section{FLOOD-CREST ELEVATIONS}

The availability of flood-profile data is essential to the solution of engineering and planning problems. Examples are the proper design of structures on flood plains and the evaluation of flood-prone areas for land-use regulation and flood-insurance rates. Water-surface profiles are affected by obstructions, contractions, and expansions of the channel; roughness of the bed, banks, and overflow areas; changes in alinement of the channel; and flow of tributaries. For example, an abrupt change in profile occurs at many bridges as upstream and downstream surface elevations fluctuate. A steep gradient of a stream flowing under a bridge indicates that, at the time of the crest, the bridge structure controlled the elevation of the upstream surface to some extent. Hydraulic characteristics of the channel downstream from the bridge control the water-surface elevation below the bridge. Accumulations of debris, channel enlargement, or fill could alter the amount of water flowing under the bridge and may also affect the areal extent of flooding upstream from the bridge.

Flood-crest data for Crosswicks Creek and tributaries of the August 28-September 1, 1978 flood were obtained by USGS employees using standard procedures (see table 3). Flood-crest data gathered by the USGS at the same locations during the flood of August 28, 1971 are also included in this table for comparison. These data define the actual crest stages occurring at the time of the two mentioned floods. Any or all of the conditions described in the above paragraph may be applicable.

\section{FLOOD DAMAGE}

Although no human lives were lost during this flood, some farm animals and family pets were drowned. Flood related injuries were reported, which included: heart attacks from excitement and exertion, sprained backs as a result of removing household goods from the floodway, and injuries resulting from automobile accidents due to hazardous conditions after the storm. Flooded highways and broken telephone lines delayed the administration of first aid and transportation of the victims to the hospital.

Damage was extensive in New Egypt and vicinity. Losses, as reported by the Burlington County Times, were estimated at over 2 million dollars, with 70 homes and 14 businesses damaged.

The above information was gathered from people living in the flooded area and from the Burlington County Times (September 1 and 2,1978 ). 
Table 3.-Flood-crest data for selected sites in Crosswicks Creek basin

\begin{tabular}{|c|c|c|c|c|c|c|}
\hline \multirow[b]{2}{*}{ Strean and location } & \multirow[b]{2}{*}{$\begin{array}{l}\text { Distance } \\
\text { above } \\
\text { mouth }\end{array}$} & \multirow[b]{2}{*}{$\begin{array}{l}\text { Site } \\
\text { reference }\end{array}$} & \multicolumn{2}{|c|}{ Flood of August 28, 1971} & \multicolumn{2}{|c|}{ Flood of August 31,1978} \\
\hline & & & $\begin{array}{l}\text { Elevation } \\
\text { NGVD } \\
(f t)\end{array}$ & $\begin{array}{l}\text { Discharge } \\
\left(\mathrm{ft}^{3} / \mathrm{s}\right)\end{array}$ & $\begin{array}{l}\text { Elevation } \\
\text { NGVD } \\
(\mathrm{ft})\end{array}$ & $\begin{array}{l}\text { Discharge } \\
\left(\mathrm{ft}^{3} / \mathrm{s}\right)\end{array}$ \\
\hline $\begin{array}{l}\text { Nortin Run at Wrightstown } \\
\text { Jobstown Road }\end{array}$ & & $\begin{array}{l}\text { upstreain } \\
\text { downstream }\end{array}$ & & & $\begin{array}{l}124.2 \\
123.4\end{array}$ & \\
\hline $\begin{array}{l}\text { North Run at MeGuire } \\
\quad \text { Air Force Base (opposite main gate) }\end{array}$ & & $\begin{array}{l}\text { upstrean } \\
\text { downstream }\end{array}$ & & & $\begin{array}{l}112.2 \\
106.3\end{array}$ & 399 \\
\hline $\begin{array}{l}\text { Crosswicks Creek Trib. } 2 \text { at } \\
\text { Lakewod Avenue, New Egypt }\end{array}$ & & $\begin{array}{l}\text { upstrean } \\
\text { downstream }\end{array}$ & & & $\begin{array}{l}92.1 \\
84.7\end{array}$ & 333 \\
\hline $\begin{array}{l}\text { Stony Ford Brook at Moorehouse } \\
\text { Road, New Egypt }\end{array}$ & & $\begin{array}{l}\text { upstrean } \\
\text { downstream }\end{array}$ & & & $\begin{array}{l}80.5 \\
78.1\end{array}$ & \\
\hline $\begin{array}{l}\text { Stony Ford Brook at Bridge } \\
\text { Road, New Egypt }\end{array}$ & & $\begin{array}{l}\text { upstream } \\
\text { downstrean }\end{array}$ & & & $\begin{array}{l}74.1 \\
73.0\end{array}$ & \\
\hline $\begin{array}{l}\text { Crosswicks Creek at } \\
\text { Route 528, New Egypt }\end{array}$ & $\begin{array}{c}19.6 \mathrm{mi} \\
(117,600 \mathrm{ft})\end{array}$ & $\begin{array}{l}\text { upstream } \\
\text { downstrean }\end{array}$ & $\begin{array}{l}69.8 \\
69.5\end{array}$ & 1,940 & $\begin{array}{l}73.7 \\
73.7\end{array}$ & 4,500 \\
\hline $\begin{array}{l}\text { Crosswicks Creek at } \\
\text { Route } 537 \text {, New Egypt }\end{array}$ & $\begin{array}{l}18.3 \mathrm{mi} \\
(110,200 \mathrm{ft})\end{array}$ & $\begin{array}{l}\text { upstream } \\
\text { downstrean }\end{array}$ & $\begin{array}{l}65.4 \\
65.2\end{array}$ & & $\begin{array}{l}68.4 \\
68.0\end{array}$ & \\
\hline $\begin{array}{l}\text { Crosswicks Creek at } \\
\text { Arneystown }\end{array}$ & $\begin{array}{l}17.0 \mathrm{mi} \\
(103,000 \mathrm{ft})\end{array}$ & $\begin{array}{l}\text { upstream } \\
\text { downstream }\end{array}$ & $\begin{array}{l}60.5 \\
60.3\end{array}$ & & $\begin{array}{l}62.1 \\
61.7\end{array}$ & \\
\hline $\begin{array}{l}\text { Crosswicks Creek at } \\
\text { Walnford }\end{array}$ & $\begin{array}{l}14.2 \mathrm{mi} \\
(87,200 \mathrm{ft})\end{array}$ & $\begin{array}{l}\text { upstreain } \\
\text { downstreain }\end{array}$ & 47.9 & & $\begin{array}{l}48.1 \\
48.0\end{array}$ & \\
\hline $\begin{array}{l}\text { Crosswicks Creek at } \\
\text { Ellisdale }\end{array}$ & $\begin{array}{l}12.3 \mathrm{mi} \\
(73,800 \mathrm{ft})\end{array}$ & $\begin{array}{l}\text { upstream } \\
\text { downstrean }\end{array}$ & $\begin{array}{l}41.5 \\
40.8\end{array}$ & & $\begin{array}{l}41.8 \\
41.6\end{array}$ & \\
\hline $\begin{array}{l}\text { Crosswicks Creek at Extonville } \\
\text { (USGS gaging station) }\end{array}$ & $\begin{array}{l}11.5 \mathrm{mi} \\
(68,800 \mathrm{ft})\end{array}$ & $\begin{array}{l}\text { upstream } \\
\text { downstrean }\end{array}$ & $\begin{array}{l}38.9 \\
38.9\end{array}$ & $\begin{array}{c}4,640 \\
\text { (revised) }\end{array}$ & $\begin{array}{l}39.2 \\
39.1\end{array}$ & 4,860 \\
\hline $\begin{array}{l}\text { Crosswicks Creek at } \\
\text { Iron Bridge Road }\end{array}$ & $\begin{array}{l}10.5 \mathrm{mi} \\
(62,300 \mathrm{ft})\end{array}$ & $\begin{array}{l}\text { upstream } \\
\text { downstreain }\end{array}$ & $\begin{array}{l}35.9 \\
35.3\end{array}$ & & $\begin{array}{l}36.3 \\
36.1\end{array}$ & \\
\hline $\begin{array}{l}\text { Crosswicks Creek at } \\
\text { Crosswicks }\end{array}$ & $\begin{array}{l}8.9 \mathrm{mi} \\
(47,000 \mathrm{ft})\end{array}$ & $\begin{array}{l}\text { upstream } \\
\text { downstrearn }\end{array}$ & $\begin{array}{l}26.0 \\
25.8\end{array}$ & & $\begin{array}{l}26.2 \\
25.8\end{array}$ & \\
\hline $\begin{array}{l}\text { Crosswicks Creek at New } \\
\text { Jersey Turnpike }\end{array}$ & $\begin{array}{l}7.4 \mathrm{mi} \\
(43,900 \mathrm{ft})\end{array}$ & $\begin{array}{l}\text { upstreain } \\
\text { downstream }\end{array}$ & $\begin{array}{l}23.6 \\
22.8\end{array}$ & & & \\
\hline Crosswicks Creek at Groveville & $\begin{array}{c}5.8 \mathrm{mi} \\
(33,700 \mathrm{ft})\end{array}$ & $\begin{array}{l}\text { upstream } \\
\text { downstrean }\end{array}$ & $\begin{array}{l}18.3 \\
18.1\end{array}$ & & $\begin{array}{l}16.8 \\
16.8\end{array}$ & \\
\hline Crosswicks Creek at Route 130 & $\begin{array}{c}5.1 \mathrm{mi} \\
(29,800 \mathrm{ft})\end{array}$ & $\begin{array}{l}\text { upstrean } \\
\text { downstream }\end{array}$ & 14.1 & & $\begin{array}{l}13.2 \\
12.8\end{array}$ & \\
\hline
\end{tabular}


Thunderstorms lasting approximately 6 hours caused flooding in the New Egypt-Wrightstown-Fort Dix area on August 31September 1, 1978. The area of precipitation was small, encompassing a radius of less than $5 \mathrm{mi}$, but rainfall in excess of 9 inches was recorded near the storm's center. Several streams were flooded, including Crosswicks, Blacks, Crafts, and Assiscunk creeks. The flooding of Crosswicks Creek in the vicinity of New Egypt has a probability of being exceeded on the average once in 75 years. Several other locations had floods with a probability of being exceeded on the average once in 20 to 30 years. See table 2, p. 8, for flood stages and discharges.

\section{REFERENCES CITED}

Burlington County Times, September 1, 2, 1978.

National Oceanic and Atmospheric Administration, 1978,

Climatological Data-New, Jersey, Volume 83, Nos. 8, 9, August and September 1978 .

Stankowski, S. J., and Velnich, A. J., 1974, A Summary of Peak Stages and Discharges for the Flood of August 1973 in New Jersey: U.S. Geological Survey Open-File Report, 12 p.

U.S. Geological Survey 1978, Water Resources Data for New Jersey NJ-78-1, water Year 1978, Volume 1, Atlantic Slope Basins, Hudson River to Cape May, $558 \mathrm{p}$.

U.S. Geological Survey, 1978, water Resources Data for New Jersey NJ-78-2, Water Year 1978, Volume 2, Delaware River Basin and Tributaries to Delaware Bay, $302 \mathrm{p}$.

U.S. Water Resources Council, 1977, Guidelines for Determining Flood Flow Frequency: Bulletin 17A of the Hydrology Committee, $183 \mathrm{p}$. 
SELECTED FLOOD REPORTS BY THE U.S. GEOLOGICAL SURVEY

Hollister, G. B., and Leighton, M. O., 1903, The Passaic Flood of 1902: U.S. Geological Survey Water-Supply and Irrigation Paper No. $88,56 \mathrm{p}$.

Leighton, M. O., 1904, The Passaic Flood of 1903: U.S. Geological Survey Water-Supply and Irrigation Paper No. 92, 48 p.

Murphy, E. C., 1906, Destructive Floods in the United States in 1905: U.S. Geological Survey Water-Supply and Irrigation Paper No. 162, $105 \mathrm{p}$.

Grover, N. C., 1937, The Floods of March 1936: Part 2, Hudson River to Susquehanna River Region: U.S. Geological Survey Water-Supply Paper $799,380 \mathrm{p}$.

U.S. Geological Survey, 1947, Minor Floods of 1938 in the North Atlantic States: U.S. Geological Survey Water-Supply Paper $966,426 \mathrm{p}$.

Paulson, C. G., 1960, Hurricane Floods of September 1938: U.S. Geological Survey Water-Supply Paper 867, 562 p.

Bogart, D. B., 1960, Floods of August-October 1955 New England to North Carolina: U.S. Geological Survey Water-Supply Paper $1420,854 \mathrm{p}$.

Rostvedt, J. 0., 1965, Summary of Floods in the United States during 1960: U.S. Geological Survey Water-Supply Paper $1790-\mathrm{B}, 147 \mathrm{p}$.

Rostvedt, J. O., and others, 1972, Summary of Floods in the United States during 1968: U.S. Geological Survey Water-Supply Paper 1970-B, 73 p.

Stankowski, S. J., 1972, Floods of August and September 1971 in New Jersey: New Jersey Department of Environmental Protection, Division of Water Resources Special Report 37, $350 \mathrm{p}$.

Stankowski, S. J., and Velnich, A. J., 1974, A summary of peak stages and discharges for the flood of August 1973 in New Jersey: U.S. Geological Survey Open-File Report, 12 p.

Stankowski, S. J., Schopp, R. D., and Velnich, A. J., 1975, Flood of July 21, 1975 in Mercer County, New Jersey: U.S. Geological Survey Water-Resources Investigations 51-75, $52 \mathrm{p}$.

Schopp, R. D., and Velnich, A. J., 1979, Flood of November 8-10, 1977 in Northeastern and Central New Jersey: U.S. Geological Survey Open-File Report 79-559, $33 \mathrm{p}$. 